\title{
Psychological exhaustion of nursing professionals who care for patients with neoplasms
}

\author{
Esgotamento psicológico de profissionais de enfermagem que cuidam de pacientes com neoplasias \\ Agotamiento psicológico de profesionales de enfermería que cuidan de pacientes con neoplasias
}

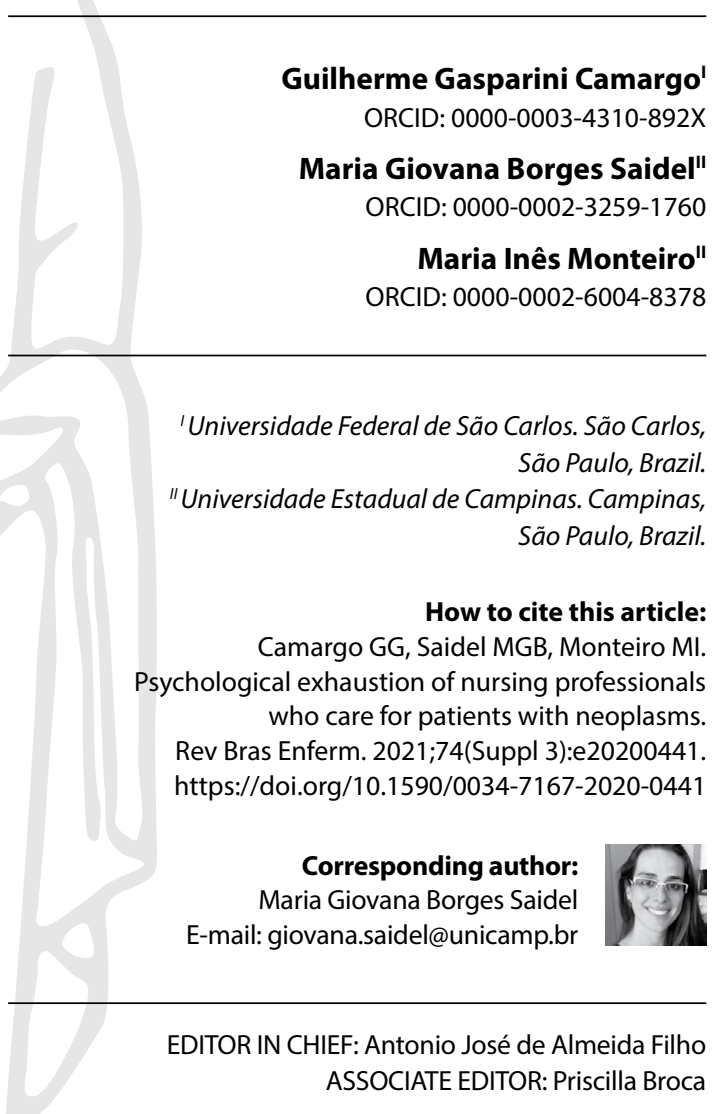

Submission: $07-07-2020$

Approval: 11-01-2020

\begin{abstract}
Objective: Identify, analyze and understand the social representations of nursing professionals about burnout syndrome. Method: Qualitative study with nursing professionals who worked in the direct assistance to oncologic patients, conducted through semi-structured interview, using the technique of content analysis, anchoring the interpretations in the theory of social representations. Results: Seven professionals participated; after analysis, two categories emerged: "The stress of professionals, the naturalization of suffering and selfcare strategies"; and "Ressignifications, learning in the oncologic sector and network gaps". The representations about stress and the relationship of the professionals with the daily practice were predominant. Final Considerations: The nursing professionals represented the burnout syndrome socially as stress and made important reflections on the subject in the context of daily work. Concepts that determine the behavior of professionals were perceived as mechanisms of confrontation. In the vision of this social group, spirituality was revealed as a therapeutic strategy.
\end{abstract}

Descriptors: Psychological Exhaustion; Nursing Professionals; Neoplasms; Mental Health; Psychological Adaptation.

\section{RESUMO}

Objetivo: Identificar, analisar e compreender as representações sociais dos profissionais de enfermagem sobre a síndrome de burnout. Método: Estudo qualitativo com profissionais de enfermagem que atuavam na assistência direta a pacientes oncológicos, conduzido mediante entrevista semiestruturada, com uso da técnica de análise de conteúdo, ancorando as interpretações na teoria das representações sociais. Resultados: Participaram sete profissionais; após análise, emergiram duas categorias: "O estresse dos profissionais, a naturalização do sofrimento e estratégias de autocuidado"; $\mathrm{e}^{\text {"Ressignificações, aprendizados }}$ no setor oncológico e as lacunas da rede". Predominaram as representações sobre estresse e relação dos profissionais com o cotidiano da prática. Considerações finais: Os profissionais de enfermagem representaram socialmente a síndrome de burnout como estresse e fizeram reflexões importantes sobre a temática no contexto de trabalho cotidiano. Conceitos que determinam o comportamento dos profissionais foram percebidos enquanto mecanismos de enfrentamento. Na visão desse grupo social, a espiritualidade revelou-se como estratégia terapêutica.

Descritores: Esgotamento Psicológico; Profissionais de Enfermagem; Neoplasias; Saúde Mental; Adaptação Psicológica.

\section{RESUMEN}

Objetivo: Identificar, analizar y comprender representaciones sociales de profesionales de enfermería sobre el síndrome de burnout. Método: Estudio cualitativo con profesionales de enfermería que actuaban en asistencia directa a pacientes oncológicos, conducido mediante entrevista semiestructurada, con uso de técnica de análisis de contenido, basado en la teoría de las representaciones sociales. Resultados: Participaron siete profesionales; tras análisis, emergieron dos categorías: “El estrés de los profesionales, la naturalización del sufrimiento y estrategias de autocuidado"; y "Resignificaciones, aprendizajes en el sector oncológico y las lagunas de la red". Predominaron las representaciones sobre estrés y relación de profesionales con el cotidiano de la práctica. Consideraciones finales: Profesionales de enfermería representaron socialmente el síndrome de burnout como estrés e hicieron reflexiones sobre la temática en el contexto de trabajo cotidiano. Conceptos que determinan el comportamiento de profesionales han percibidos cuando mecanismos de enfrentamiento. La espiritualidad se reveló como estrategia terapéutica.

Descriptores: Agotamiento Psicológico; Profesionales de Enfermería; Neoplasias; Salud Mental; Adaptación Psicológica. 


\section{INTRODUCTION}

The current scenario of nursing practices has contributed to the psychic illness of professionals. In national and international scope, it is observed the expressive high in the incidence of burnout syndrome (BS) among nursing professionals. It is a psychosocial disorder characterized by depersonalization, emotional exhaustion and reduced productivity. They contribute for its expressive increase: the conditions of work environment, work and dimensions of the care, as contact with the suffering, illness, death, anxiety and stress ${ }^{(1-2)}$. In this context, there are several sectors that are considered critical for the predisposition to the development of mental diseases, psychic symptoms and exhaustion, such as intensive care units; pediatric units; and oncologic units ${ }^{(3-4)}$.

Throughout the work processes in the care of the oncologic patient, conditions are added that can become triggers for the development of burnout syndrome, among them: the social stigma about the disease; the frequent association with death, suffering and punishment; high number of cases of poor prognosis; and the stress inherent to the profession. These factors can amplify the feeling of impotence of the nursing professional before the care ${ }^{(5-6)}$.

With the purpose of bringing out and rescuing affective characteristics in the daily life of the caregiver, the nurse professional is attributed the need for a holistic vision of care on the team professionals, identifying early factors that may harm their mental health. In this sense, some behaviors and information can facilitate this mapping, of which the following stand out: frequent delays and/or unjustified absences at work; verbalization of sadness; uneasiness; feeling of powerlessness; and pre-existing mental disorder ${ }^{(7)}$.

This early identification is fundamental, because the burnout syndrome, among other mental disorders, may be co-responsible for negative outcomes related to work processes. Among these outcomes, it can be emphasized the damage to the surveillance of important aspects of the profession for the patient's safety. A recent international study reported that nurses with a high professional burnout score tend not to correctly follow international techniques and protocols, such as hand hygiene. This behavior can often lead to increased risks of infection to patients ${ }^{(8)}$.

The conducts and actions for previous prevention and identification practices are numerous and can help nurses and managers in the important execution of this early diagnosis, in order to reduce the negative impact on the work process. Among these actions, teaching strategies and promotion of coping skills, awareness of the multidisciplinary team, self-assessment questionnaires, continuous and permanent education, space for dialogue with active communication and reflection supported by the organizational culture of the environment are evidenced ${ }^{(7)}$.

The dialogic representations of the present study seek to portray the way of construction of knowledge about practices of nursing professionals in the care of the oncologic patient, reflecting, as social actors, the elaboration of concepts and understandings about the psychological exhaustion, process of death and dying, psychological adaptation in face of stress and reflection about its limitation in nursing care. Moreover, the social representation allows to clarify the place that the representation occupies in the societies that make reflections on diverse subjects, anchored in the naturalization of the reality.

By understanding, through the identification of social representations, the socially constructed and shared phenomena, it is possible to make familiar concepts and ideas in the processes of satisfying the argumentative reasoning of common sense. In order to interpret the daily life of people or social groups, social phenomena are considered an indispensable resource ${ }^{(9)}$. They constitute an important nursing instrument for the critical organization of social and scientific knowledge in health organizations.

In view of the theoretical construction approached, this research had the following question: What are the social representations about the burnout syndrome of nursing professionals who act in the care of oncologic patients?

\section{OBJECTIVE}

Identify, analyze and understand the social representations about burnout syndrome built by nursing professionals who act in the direct care of oncologic patients.

\section{METHODS}

\section{Ethical aspects}

The study was submitted to the standards established by Resolution No. 466 of December 2012 of the National Health Council of the Ministry of Health and was approved by the Ethics and Research Committee. All participants in the study signed the Term of Free and Informed Consent. The identities were preserved by assigning plant names to the participants and by hiding excerpts that could evoke some identification facilitator data.

\section{Theoretical and methodological reference}

Serge Moscovici's social representations theory (SRT) was used. This theoretical-methodological reference ${ }^{(10)}$ studies representations that people have collectively about aspects of life context. It also seeks to understand how this knowledge, arising from the representations, transacts between individuals forming thought structures that focus on individual and group behaviors.

SRT is supported by a transdisciplinary theoretical and methodological foundation (sociology and psychology), as described in Moscovici's work ${ }^{(9)}$; in this sense, it stands on the frontier of contemporary social theory ${ }^{(10)}$. The objective of all representations is the transformation in the individual of something (object and/or phenomenon) not familiar into something familiar. The essential concepts that produce and build social representations are the anchorage (process in which the individual seeks to classify and find a place, naming something to understand the non-familiar) and the objectification (elaboration of concepts and images to reproduce in the world outside the individual). Reality, in SRT, is divided into a consensual universe, which expresses activities related to common sense and theories to answer the problems that are imposed, in which individuals elaborate their construction of reality based on the environment where they live, explaining things without necessarily being a scientist or specialist - in this 
universe, social representations hatch; and a reified universe, which manifests scientific knowledge and knowledge, with objectivity and logical and methodological rigor. However, it should be emphasized that both universes interrelate, giving shape to reality ${ }^{(9)}$.

\section{Type of study}

It is an exploratory, descriptive, transversal research, with a qualitative design. It should be noted that qualitative research is characterized by not using statistical instruments to support the process of analysis of a phenomenon. Therefore, it is not intended to number or measure homogeneous units or categories, but there is the pretension to understand these phenomena already described $^{(11)}$. The Consolidated Criteria for Reporting Qualitative Research (COREQ) criteria for qualitative research served as a roadmap for the reports of this study.

\section{Methodological procedures}

\section{Study scenario}

The study scenario was an oncology sector of a public hospital in a city in the interior of São Paulo, which integrates the High Complexity Assistance Units (UNACON) for cancer care in the state of São Paulo, and which has been accredited since 2008.

\section{Data sources}

The population of the study was composed of nursing professionals (nurses and nursing technicians) of the oncology sector. As inclusion criteria, the professionals that had more than one year of performance in the direct assistance to the patient with cancer were considered.

For sample composition, the intentionality criterion was used and, for its closure, the theoretical saturation ${ }^{(11)}$. For the latter, the proposal and procedures described by Fontanella et al. were employed in order to establish the final sample size ${ }^{(12)}$.

Seven nursing professionals participated in the study - remembering that, for a project with a unique field of data collection, a qualitative sample size of six to ten interviews is considered sufficient for understanding the phenomenon ${ }^{(13)}$. For the final codification of the interviews and preservation of the identity of the participants, the names of medicinal plants were used to replace the names of the interviewees (Rosemary, Balsam, Barbatimão, Calendula, Chamomile, Sage and Aloe.

\section{Data collection and organization}

After the project approval and before the effective data collection, an acculturation process was performed by the researcher - in the case of qualitative studies, it is an important step for the validity and credibility of the research ${ }^{(11)}$. This journey had two stages: 1) initially, visits and informal conversations were made with the local manager and nursing professionals to explain about the research; and 2) in a second moment, a pilot interview, with the objective of improving the instrument of data collection. This initial interview was transcribed; and after peer validation, adjustments were made to the guiding questions. It should be noted that such interview does not make up the final sample. After the period of acculturation and approximation of the researcher - who had technical formation in nursing, did not belong to the unit that was a field of study and did theoretical immersion previously about the thematic - the collection of data began, then.

Individual semi-structured interviews were conducted with nursing professionals for a period of four months (May to August 2015). In order to direct the interviews, a script was prepared with guiding questions: 1) How do you perceive the burnout syndrome and how it can impact the work processes? 2) How do you deal with stress? 3) How do you perceive your daily work? The interviews took place in a private place, during working hours, with the collaboration of the nurse manager; they were recorded and later transcribed in full for the systematization of the data analysis.

\section{Data Analysis}

After the full transcription of the interviews, a corpus of seven texts was created, which were submitted to content analysis. In this technique of analysis, researchers discover the nuclei of meaning that will compose the communication; and there is the breakdown of the text into units of categories for subsequent analytical regrouping. This type of analysis comprises three stages: pre-analysis; exploration of the material; treatment of the data and interpretation ${ }^{(11)}$. Therefore, in this last stage, the theoretical-methodological reference of the theory of social representations was used to support the interpretations and subsequent discussion.

\section{RESULTS}

The sample was composed by seven female professionals (two nurses and five nursing techniques), aged between 22 and 50 years. Regarding marital status, there were five married/ stayed, one single and one divorced. As for ethnicity, five were considered white; one, black; and one, brown. As for receiving emotional support within the health service, six said yes and one said no. Regarding the use of alcohol, one often consumes, four do not consume and two have already consumed and today no longer consume. Regarding the use of psychotropic drugs, five refer to making use and two do not. The interviews lasted a minimum of 28 minutes and a maximum of one hour and 36 minutes. After analysis, the corpus was composed of seven texts, which totaled 98 pages in Word A4 document and corresponded to the transcriptions of the participants' speeches. Once the content analysis was done, two categories emerged, which will be presented and discussed below.

\section{The stress of professionals, the naturalization of suffering and self-care strategies}

During the interview, the professionals had initial difficulty in answering the guiding question, and the researcher had to have 
several communication techniques so that they could verbalize the stress they felt when dealing with direct assistance to the oncologic patient. The social representations of the group showed that stress is one of the expressions of the burnout syndrome identified by the professionals; however, in the interviews, it is common to use the term "stress", but they don't associate it with the syndrome; they don't even mention it nominally. In the reports, it is possible to perceive a feeling of revolt regarding the situation experienced by the patient, because there is the affection of the professional and the "attachment" to the person, since, many times, they are years of treatment in the same sector.

It is possible to perceive the social being in adaptation to his circumstances, thus reverberating social representations through life experiences ${ }^{(9)}$.

We get a little angry in some cases, right? Because there is a patient that we are very attached to, we say, "Ours is such a good person and has this disease"... you get angry, there is a time that you get very angry. (ROSEMARY)

We try not to get too attached to the person, but from the moment it arrives, we see it every day. Then the person goes to death, then he or she is felt, cries if necessary, but it's momentary, you can't take that daily, but... (BARBATIMÃO)

Considering the concept of implicit relevance of qualitative designs $^{(11)}$, there is a process of naturalization of suffering, as if daily work processes offered, over time, a protection to stress and, consequently, to burnout syndrome.

In the beginning, we suffer a little more, because we have to learn to deal with things that we don't know how to deal with [...] there is a moment that needs the hug and we need to give the hug, because oncology is a sector that you live a lot with the patients, and we create the affection. (ALOE)

There are some cases of patients that shock us more; sometimes you remember and get sad, but you go, I don't say getting used to it, but you learn how to deal with the situation, nah? (ROSEMARY)

Attempts to conceptualize stress are observed. This dialectical process is fundamental for the formation of social representations; making something familiar requires processes of reflection and repetition. These movements, in the future, will bring out anchorage and objectification ${ }^{(9)}$.

Symptoms of burnout syndrome (described in the introduction) can be seen in the lines. Once again, the naturalization of stress comes with the concept, as a common feeling, also occurring the direction of the relationship of stress with the occupational environment.

The stress, I think it's a little bit like that, anxiety, a mental fatigue, the day to day is stressful, you know? (CALENDULA)

For me, stress is something that is common throughout the environment, everywhere. The problem is when you run out of control; sometimes there are situations that get out of control and take you a little off the axis. For me, it's something that I can handle well in the whole. (ALOE)
For me, stress is a whole issue that generates emotional discomfort, right? At work, both the relationship with co-workers. (BALSAM)

In the data collected, it is possible to perceive in the speech the construction of the concept of stress associated with issues of behavior, as an attempt to justify the emotion through the way of glimpsing the daily life.

Actually, I think I'm a little stressed, yes, but I like the right things [...]. Everything the person said to me, was agreed, has to be that. So that makes me very stressed. (SAGE)

The process of suffering experienced by patients in daily life and witnessed by professionals brings questions about procedures inherent to nursing. However, when they are performed in oncology and without success, they can become a source of suffering.

I have, I have, and l expose it with my boss. For example, there was a patient here who I couldn't puncture his vein... I get very bad, I feel powerless, I keep thinking "because I didn't try again, because guy didn't try..." (CALENDULA)

From this perspective, it is necessary to describe some data collected about how they deal with stress, which may become the burnout syndrome. The nursing professionals demonstrate an informal attempt of self-care, as if the work processes associated to the personal experiences edify informal strategies, so that the context is not only source of suffering. These actions are described below as informal conversations, supporting the concept of communication as therapeutic and the spiritual practices, that offer comfort to the daily anguishes.

Ijust really vent [...]. A little relieved, but not that it will solve, I go talking with my mother, with a friend, not that it will solve, but it improves. (BALSAM)

I usually pray a lot, I pray to God that the person doesn't suffer, I try to vent it too, [...] / try to vent it with family and friends because I think that talking to someone from the outside gets better. (CALENDULA)

\section{Resignations, learning in the oncology sector and the gaps in the network}

In this category, it was highlighted the verbalization of resignifications and learning of nursing professionals in the conviviality with cancer patients. There are reports of direct and indirect benefits of this daily experience with people who face the disease and often have poor prognosis. Sensations and reflections about life, values and the present moment permeate the representations of these professionals, as well as considerations about posture - for example, "complaints" and teachings from patients who are being cared for.

But you feel [...] that we have to give more value to today, to what we have, we have to do today because tomorrow it may be me who is in this situation; nobody is subject to not having or having, we live a lot with a patient who is debilitated and who is terminal phase. (SAGE) 
I think we complain too much about everything, and there are patients who give us a lesson in life, especially those with terminal cancer; they have strength that they bring hope to us [...]. (ROSEMARY)

It also stands out resignifications about the work process, even in the perception that the assistance to the patient with cancer is difficult and sad, there are moments of learning. There are representations that reveal the pride in working in this sector, showing an important counterpoint in the daily life of these professionals.

People's perception of oncology is usually darker and more depressing. So people think they're going to come in here and they think they're going to see only people dying, we who work here know that there are those who heal themselves and those who die, but inside all this we have a very big learning. Ileave here more animated [...] I'm praised. (ALOE)

Reinforcing the findings in this category, the professionals considered as a source of learning the conviviality with oncologic patients, benefiting, thus, of the knowledge and learning experienced by them. During the reports, it was possible to identify factors that affirm that the knowledge can come from both sides, the professional and the patient, including those in advanced stage of the disease.

Despite the reports of resignifications and learning, a counterpoint is presented that demonstrates how much these professionals are able to elaborate reflexive processes in their work contexts within the network operation. The speech below reports that it is necessary to go beyond learning about subjective issues, being important the preparation and development of communication skills, because many patients come to the service with little or no information about the disease. In this sense, it is up to this professional to structure information so that there is knowledge sharing.

Today I realize that there is a flaw in the system, and this patient when he discovers the evolved disease, he does not have the perception of the picture he will face, of this process [...]. And when he looks for the service, usually the diagnosis is already a little bad, he can't understand that this disease started at a certain moment and it went to that point, because he discovers at the most critical moment in most cases. (ALOE)

\section{DISCUSSION}

In this discussion, a triangulation is made with the reified universe of the theme, through research that corroborates the representations found in the consensual universe of the interviewed professionals.

The social representation of the burnout syndrome is reflected in the discourse that refers to the concept of stress, initially approached with the association between the feelings of affection towards the patient and the stress experienced by the health professional.

In this sense, the social representation of the burnout syndrome is associated with the concept of stress, and it is the way health professionals perceive it, it is the consensual knowledge, that is, of the common sense, of the daily work, making something unfamiliar (burnout syndrome) become something familiar (stress), the anchoring process $^{(9)}$ - in this case, stress. Compassion fatigue and high emotional burden, characterized as physical and mental exhaustion caused by the care for the other, are related to the care for oncologic patients ${ }^{(3)}$.

The daily exposure to stress in work environments and the lack of both an accurate look of managers and systematic psychological support by the institution can slow down or hide professionals who are in psychic distress. The absence of social and managerial support that guarantees care to professionals can generate a "second victim" in the clinical context. Frequent conflicts in work relations, tension, unpleasant work environment and decrease in the quality of life of the caregivers are some indicators related to the psychological illness of the professional|(14). However, early detection of signs and symptoms of exhaustion as well as actions to prevent mental disorders and promote the mental health of the worker are essential to take care of those who care ${ }^{(15-16)}$.

For this, as evidenced in the representations, the search for spiritual questions finds echo in international literature. A qualitative study conducted in Iran reported on the need to develop spiritual assistance programs. It describes the importance in learning to provide spiritual care in nursing schools as well as in the continuing education sectors ${ }^{(16)}$.

It is observed that when individuals identify personal and professional limitations, it is common to resort to questions of spirituality as a way to request protection or even explanation ${ }^{(17)}$. In this sense, questions about this theme are already inserted as a dimension of nursing care. The consequences of nursing actions in this context have demonstrated mutual benefits in the process of care ${ }^{(18)}$. It should be emphasized that spiritual care is not synonymous of imposing a certain religion on someone, but ways of caring that should be integrated to the beliefs and values of professionals, without this being imposed; it would be like an extra strategy in this context. Also, it is pointed out that this kind of strategy arose from the speeches of professionals, that is, from the consensual universe of participants, and that it finds resonance in the reified universe, in national and international literature.

It is important that the discussion about the naturalization of stress in the oncologic environment be expanded. The daily activities in this context seem to make the nursing professionals interviewed naturalize feelings that cause psychic suffering. There is a representation that these sensations, emotions and feelings are inherent to the practice of nursing in oncology.

Such construction of the professionals demonstrates the formation of this important social representation, since it occurs by means of anchoring and objectification ${ }^{(9)}$, that is, the idea of work in oncology is always stressful, and soon the feeling is naturalized, that is, its objectification. These are the social actors transmuting the unfamiliar into familiar ${ }^{(9)}$ as a way to minimize the suffering, fear and anguish of the work they are in. However, it is necessary to take a close look at these processes, because they can hide important sufferings of these professionals, because they have the belief that it is normal to feel stress, anguish, fear and other negative feelings once they act in the care of the oncologic patient. This"normalization" may delay the professionals' search for psychological or other support, which could result in aggravation of this stress.

Proposals that allow spaces for discussion and reflection are primordial, because the processes of work in oncology are powerful in the sense of producing constructions on paradigms of the life of these 
professionals. These constructions in organized and systematized spaces within the institutions can collaborate for the resilience of these workers, being a protective factor for mental disorders.

Resilience involves the process of positive adaptation to stress and adversity. In an integrative review, authors highlighted the frequent presence, in some countries, of programs that worked with the resilience of the nursing professional. In the study, such actions were able to regulate thoughts and emotions of these workers. In their considerations, the authors encourage the development and implementation of programs and strategies to build resilience in health organizations ${ }^{(18)}$ In this study, it was possible to analyze processes of resignification, denoting an optimistic and learning vision.

Therefore, it should be noted that this is a cut-off and that this may not be the reality in other scenarios, since different results have been described at the national and international level(19-20).

In addition, psychotherapeutic intervention programs for professionals affected by excessive emotional burden have been strengthening among the scientific means, such as meditation and mindfulness. The use of technology can be an ally for stress reduction and prevention in the development of psychosocial pathologies. The use of cell phone applications with mindfulness is one of the alternatives in the post-modern world and has been shown to improve in people affected by the syndrome ${ }^{(3)}-$ a technology of low cost and that makes possible results evidenced in the literature. It is necessary to train and prepare nurse managers with respect to the knowledge of the team and mapping of the workers' profiles, both social and epidemiological; moreover, it is necessary to think in a systematic way about alternatives to protect and take care of nursing professionals who work in oncology.

In the theory of social representations, information is the organization of the knowledge that a group possesses regarding a certain social object ${ }^{(9)}$. Thus, the nursing professionals demonstrated their representation of the burnout syndrome by means of a known object, that is, stress. And it is in this representation that the studied social group builds its reflections.

The attitude would be to take a position of the social group before the represented object, which, according to the SRT, has a direct impact on reality through behaviors conditioned by representation ${ }^{(9)}$. Thus, it is emphasized that the social representations about the burnout/stress syndrome will make the nursing professionals of oncology position themselves before the daily situations that bring out the beliefs emerging in this study. Therefore, the study of the social representations of the groups is important, because it makes possible to evaluate and interpret behaviors in the daily work, subsidizing future discussions and proposals that are more adequate to the studied group. This important movement would then have the objective of improving the practice in the work processes and prevent, minimize and/or take care of the psychic suffering of these professionals.

\section{Study limitations}

A limitation refers to the unique field of study, since the research was carried out in a single sector of oncology, in a public hospital in the interior of the state of São Paulo. This contributes to the process of naturalistic generalization, proper of qualitative research, but the results should not be extrapolated to other contexts, with diverse characteristics. For this reason, it is important to expand research of this nature through studies that contemplate other fields and other professionals in oncologic treatment contexts.

\section{Contributions to Nursing, Health or Public Health}

Considering the implications of social representations in the behavior of the actors in their contexts, the study manages to reveal, in the cut of the sample, how nursing workers who work in the oncology area understand the stress in this scenario. In the discussion, it was possible to perceive and understand the existence of strategies, described in the literature, some with low cost inclusive, that can be constructed together with these professionals, aiming to minimize or even to prevent the psychic suffering. Moreover, it contributed by making the figure of the managing nurse emerge and reinforce as strategic in this context, because, with preparation, he becomes able to identify initial psychic issues of the professionals, for effective and early interventions.

The representative elements emerging from this study are important when considered for the practice of humanized care, especially for professionals working in critical areas, which can cause psychic suffering.

\section{FINAL CONSIDERATIONS}

It is considered that nursing professionals have socially represented burnout syndrome as stress and have managed to make important reflections on the subject in the context of daily work. The study made a greater understanding and understanding about the object of study possible. Through the analysis and discussion of the results, it was possible to think about the concepts that determine the behavior of the professionals and, then, to perceive the mechanisms of confrontation reported, revealing the spirituality as therapeutic strategy in the vision of this social group.

The analysis and interpretation of the content made it possible to reveal the understanding of the professionals about the work processes about burnout/stress syndrome, but some results showed a naturalization of the stress experienced. This naturalization is considered a mechanism of confrontation, which could cause, in different moments, the distancing of the assistance (not the physical, but the psychic).

It is fundamental the preparation of nursing professionals for the management of their colleagues in psychic suffering. This preparation must still occur at graduation, and it is necessary that these professionals understand that, in some situations, they will have to identify nursing workers who present symptoms of physical and mental exhaustion early. It is important, therefore, the instrumentalization for the self-care of these professionals, offering strategies so that, in the daily life, they manage to implement them as much for their team as for themselves.

It is considered that the social representations of nursing professionals about burnout/stress syndrome were relevant and need to be widely understood, because the work apprehended by the team in the field of representations implies the analysis of reality, the process of awareness and, finally, changes in attitudes that impact the mental health of these individuals. 


\section{REFERENCES}

1. Santos FF, Brito MFSF, Pinho L, Cunha FO, Rodrigues-Neto JF, Fonseca ADG, et al. Common mental disorders in nursing technicians of a university hospital. Rev Bras Enferm [Internet]. 2020 [cited 2020 Apr 13];73(1):e20180513. Available from: https://www.scielo.br/pdf/reben/ v73n1/0034-7167-reben-73-01-e20180513.pdf

2. Baldonedo-Mosteiro M, Almeida MCS, Baptista PCP, Sánchez-Zaballos M, Rodriguez-Diaz FJ, Mosteiro-Diaz MP. Burnout syndrome in Brazilian and Spanish nursing workers. Rev Latino-Am Enfermagem [Internet]. 2019 [cited Apr 13];27:e3192. Available from: https://www. scielo.br/pdf/rlae/v27/0104-1169-rlae-27-e3192.pdf

3. Ortega-Campos E, Vargas-Román K, Velando-Soriano A, Suleiman-Martos N, Fuente GAC, Albedin-García L, et al. Compassion fatigue, compassion satisfaction, and burnout in oncology nurses: a systematic review and meta-analysis. Sustainability [Internet]. 2020 [cited Apr 14];12(1):72. https://doi.org/0.3390/su12010072

4. Tomas AJC, Ortega I, Fernandéz T, Mena ML, Raga MG, Iranzo V, et al. Impact of burn-out syndrome in oncology staff and its improvement through specific intervention. J Clin Oncol [Internet]. 2019 [cited 2020 Apr 14];37(27):249-9. https://doi.org/10.1200/JCO.2019.37.27_suppl.249

5. Santos MA. So close to the pain of the other, so close to the own insanity: the health professional and the death. Rev SPAGESP [Internet]. 2003 [cited 2020 Apr 14];4(4):43-51. Available from: http://pepsic.bvsalud.org/pdf/rspagesp/v4n4/v4n4a07.pdf

6. Borges ADVS, Silva EF, Toniollo PB, Mazer SM, Valle ERM, Santos MA. Perception of death by oncological patient along its development. Psicol Estud [Internet]. 2006 [cited 2020 Apr 14];11(2);361-9. Available from: https://www.scielo.br/pdf/pe/v11n2/v11n2a14.pdf

7. Jodas DA, Haddad MCL. Burnout Syndrome among nursing staff from an emergency department of a university hospital. Acta Paul Enferm [Internet]. 2009 [cited 2020 Apr 14];22(2):192-7. Available from: https://www.scielo.br/pdf/ape/v22n2/en_a12v22n2.pdf

8. Manomenidis G, Panagopoulou E, Montgomery A. Job burnout reduces hand hygiene compliance among nursing staff. J Patient Saf. 2019;15(4):70-3. https://doi.org/10.1097/PTS.0000000000000435

9. Moscovici S. Representações sociais: investigações em psicologia social. Petrópolis: Vozes; 2015. 262 p.

10. Dioria API, Costa MAF, Santana GCA. A teoria das Representações Sociais como referencial teórico-metodológico na pesquisa em Ensino de Biociências e Saúde. Rev Práxis [Internet]. 2017 [cited 2020 Sep 30];9(17). Available from: http://revistas.unifoa.edu.br/index.php/praxis/ article/view/685/1220

11. Minayo MCS, Deslandes SF, Gomes R. Pesquisa social: teoria, método e criatividade. Petrópolis: Vozes; 2016.96 p.

12. Fontanella BJB, Moretti LB, Borges SMG, Janete R, Ribeiro TE, Gusmão MD. Amostragem em pesquisas qualitativas: proposta de procedimentos para constatar saturação teórica. Cad Saúde Pública. 2011;27(2):388-94. https://doi.org/10.1590/S0102-311X2011000200020

13. Braun V, Clarke V. Successful qualitative research: a practical guide for beginners. London: Sage; 2013.396 p.

14. Heiss K, Clifton M. The unmeasured quality metric: burn out and the second victim syndrome in health care. Semin Pediatr Surg. 2019;28(3):189-94. https://doi.org/10.1053/j.sempedsurg.2019.04.011

15. Vidotti V, Martins JT, Galdino MJQ, Ribeiro RP, Robazzi MLCC. Burnout syndrome occupational stress and quality of life among nursing workers. Enferm Glob. 2019;18(3):344-76. https://doi.org/10.6018/eglobal.18.3.325961

16. Moosavi S, Rohani C, Borhani F, Akbari ME. Consequences of spiritual care of cancer patients and oncology nurses: a qualitative study. Asia Pac J Oncol Nurs. 2019;6(2):137-44. https://doi.org/10.4103/apjon.apjon_37_18

17. Moosavi S, Rohani C, Borhani F, Akbari ME. Factors Affecting spiritual care practices of oncology nurses: a qualitative study. Supp Care Cancer. 2019;27(3):901-9. https://doi.org/10.1007/s00520-018-4378-8

18. Rojas FR, Vásquez PC, Barboza VV, López ALS, Zavala MOQ. Psycho Social risks noted by oncology workers related to their quality of life. Rev Bras Enferm. 2019;72(4):854-60. https://doi.org/10.1590/0034-7167-2017-0833

19. Foster K, Roche M, Delgado C, Cuzzillo C, Giandinoto JA, Furness T. Resilience and mental health nursing: an integrative review of international literature. Int J Ment Health Nurs. 2019;28(1):71-85. https://doi.org/10.1111/inm.12548

20. Bordignon M, Monteiro MI, Mai S, Matins MFSV, Rech CRA, Trindade LL. Oncology nursing professionals' job satisfaction and dissatisfaction in Brazil and Portugal. Texto Contexto Enferm [Internet]. 2015[cited 2020 Sep 30];24(4):925-33. Available from: https://www.scielo.br/pdf/ tce/v24n4/0104-0707-tce-201500004650014.pdf 